\title{
Serological Monitoring of Paediatric Visceral Leishmaniasis By IFA and ELISA Methods
}

\section{IFA ve ELISA Yöntemleri ile Çocuk Visseral Leishmaniasis Serolojik İzlemi}

\author{
Nermin Şakru', Seray Özensoy Töz², Metin Korkmaz², Yusuf Özbel²
}

1Department of Medical Microbiology, Faculty of Medicine, Trakya University, Edirne, Turkey

2Department of Parasitology, Faculty of Medicine, Ege University, İzmir, Turkey

\section{ABSTRACT}

Objective: Visceral leishmaniasis (VL) is endemic in all Mediterranean countries including Turkey, and children are at greater risk than adults in endemic areas. In VL patients, serological assays are considered to be sensitive for the diagnosis and/or follow up. The aim of this study was to assess the usefulness of serology for following up of childhood VL in Turkey.

Methods: Sera obtained from twenty parasitologically confirmed children with VL were tested using IFAT and ELISA. The patients were monitored clinically and serologically (range: 20-500 days) during and after treatment. All VL patients were treated with meglumine antimonate.

Results: Anti-Leishmania antibodies in successfully treated VL patients showed a steep decline but, in three patients who had relapsed, an increase was detected. Significantly lower values were observed after treatment with both serological techniques. Mean ELISA optical density values before and after treatment were: $0.78 \pm 0.36(0.26-1.76)$ and $0.38 \pm 0.24(0.09-0.83)$ respectively, $(p<0.001)$ and mean IFAT values $\left(\log _{10}\right.$ transformed titers) before and after treatment were: $3.02 \pm 0.90(1.81-4.51)$ and $2.16 \pm 0.75(1.20-3.90)$ respectively, $(p<0.001)$.

Conclusion: ELISA and IFAT are valuable not only for diagnosis but also for monitoring of drug therapy in childhood visceral leishmaniasis as rapid and non-invasive techniques. (Turkiye Parazitol Derg 2011; 35: 125-8)

Key Words: Visceral leishmaniasis, follow up, serology, IFA, ELISA, Turkey

Received: 30.03 .2011

Accepted: 16.06 .2011

\section{ÖZET}

Amaç: Visseral leishmaniasis (VL) Türkiye'nin de içinde bulunduğu Akdeniz ülkelerinde yaygın olarak görülür ve endemik bölgelerde çocuklar yetişkinlere göre daha büyük risk altındadırlar. VL hastalarında serolojik testler tanı ve/veya izlem açısından hassas olarak kabul edilmektedir. Bu çalışmanın amacı, Türkiye'de çocukluk çağı VL izlemi açısından serolojinin yararlılığını değerlendirmektir.

Yöntemler: VL olduğu parazitolojik olarak doğrulanan yirmi çocuktan alınan serumlar IFAT ve ELISA testleriyle çalışıldı. Hastalar; tedavi süresince ve tedavi sonrasında (aralık: 20-500 gün) serolojik ve klinik olarak izlendi. Tüm VL hastaları meglumin antimonat ile tedavi edildi.

Bulgular: Başarıyla tedavi edilen VL hastalarında anti-Leishmania antikorlarında keskin bir düşüş, nüks olan üç hastada ise antikorlarda artış tespit edildi. Anlamlı düşük değerler her iki serolojik teknikle tedavi sonrasında gözlendi. Tedavi öncesi ve sonrası ortalama ELISA OD değerleri: sırasıyla $0.78 \pm 0.36(0.26-1.76)$ ve $0.38 \pm 0.24(0.09-0.83)(p<0.001)$ idi ve tedavi öncesi ve sonrası (log 10 transformed titers) IFAT ortalama değerleri ise sırasıyla $3.02 \pm 0.90(1.81-4.51)$ ve $2.16 \pm 0.75(1.20-3.90)(p<0.001)$ olarak saptandı.

Sonuç: ELISA ve IFAT testleri; sadece tanı için değil aynı zamanda hızlı ve invaziv olmayan teknikler olarak Çocuk visseral leishmaniasis ilaç tedavisi izleminde de değerlidir. (Turkiye Parazitol Derg 2011; 35: 125-8)

Anahtar Sözcükler: Visseral leishmaniasis, takip, seroloji, IFA, ELISA, Türkiye

Geliş Tarihi: 30.03.2011

Kabul Tarihi: 16.06.2011

This study was presented in $4^{\text {th }}$ World Congress on Leishmaniasis 03-07 Feb 2009, Lucknow, India.

Address for Correspondence / Yazışma Adresi: Dr. Nermin Şakru, Department of Medical Microbiology, Faculty of Medicine, Trakya University, Edirne, Turkey Phone: +90 2842357641 E-mail: nsakru@yahoo.com

doi:10.5152/tpd.2011.31 


\section{INTRODUCTION}

Leishmaniasis, a vector-born disease caused by obligative intracellular protozoa of the genus Leishmania, is capable of causing a spectrum of clinical syndromes affecting millions of people in endemic areas of the tropics and subtropics. Visceral leishmaniasis $(\mathrm{VL})$ is the most severe form and causes large-scale epidemics with a high fatality rate and is endemic in all Mediterranean countries including Turkey Children are at greater risk than adults in endemic areas $(1,2)$.

In VL patients, serological assays are considered to be sensitive for the diagnosis and/or follow-up of visceral leishmaniasis. The aim of this study was to assess the usefulness of serology for following up of childhood VL in Turkey (2-6). The most common methods of diagnosing $\mathrm{VL}$ are classical parasitological methods such as microscopical direct examination and in vitro culture of bone marrow and/or splenic aspirates (7). As these techniques require invasive procedures and are difficult to repeat for followup of patients, an easy, rapid, and non-invasive method would be valuable. Therefore, we conducted a study among all children hospitalized for VL to assess the usefulness of IFAT and ELISA tests for follow-up of VL in childhood.

\section{METHODS}

The laboratories in the Department of Parasitology of Ege University Medical School have served as the National Reference Laboratory for the diagnosis of leishmaniasis and around 150 sera and/or bone marrow samples obtained from patients suspected by clinicians according to clinical signs/symptoms as having VL have being sent by different hospitals. In the laboratory, different parasitological and serological diagnostic techniques for leishmaniasis such as direct microscopy of bone marrow samples, inoculation to NNN culture, Indirect Fluorescent Antibody Test (IFAT), ELISA and rK39 dipstick test have been used. At the time the present study was carried out, only conventional PCR was applicable but, in the last several years the others (real-time PCR, sequencing, RFLP) have also become available.

For the present study, 20 pediatric visceral leishmaniasis patients diagnosed as VL by IFAT and ELISA were selected. The selection criteria were; (i) sera and bone marrow samples being available, (ii) at least three clinical signs are suitable for $\mathrm{VL}$, (iii) immunocompetence, (iv) between the ages 1 and 14, (v) easy to access, (vi) approval of informed consent form by his/her parents.

The first samples were received before the treatment and the subsequent samples were requested during and after treatment. During the monitoring period, the medical information about the patients was requested from their physicians. If a relapse episode was suspected, samples were taken during the active phase. The time schedule was varied for each patient (range: 20 -500 days). The patient's biochemical results were not included in the study because of difficulties in accessing the results.

Culture: Between 50 and 100 micro liters of bone marrow aspirate was inoculated into NNN medium, kept at $24^{\circ} \mathrm{C}$ and examined by light microscopy every week for the presence of promastigotes for two months.

Microscopy: The smear samples prepared from bone marrow aspirate were stained with Giemsa stain. Two experienced researchers examined each slide for at least 30 minutes looking for amastigotes independently.

Serology: The first (in the time of diagnosis) and subsequent serum samples (during follow-up) were tested individually and then all samples were tested in parallel for confirmation of the serological results. The serum samples were stored at $-30^{\circ} \mathrm{C}$ until use.

IFAT was carried out using promastigotes from local $L$. infantum zymodeme MON-1 stocks obtained by mass culturing in RPMI1640 containing 10\% FCS. The IFAT was performed using standard procedures for humans (8). Slides were stained with FITClabeled anti-human IgG conjugate (BioMerieux 75692) for sera. Titers $\geq 1: 128$ were scored as positive for both groups of sera while 1/64 titer was accepted as borderline in reference to relevant publications $(9,10)$.

ELISA was performed as explained previously (11), except for the whole lysate promastigote antigen, using 1/100 single serum dilution. The optical density was measured at $405 \mathrm{~nm}$ and the subjects were considered as positive when the OD was $>0.300$, which represents the mean plus $3 \times \mathrm{SD}$ absorbencies obtained in sera from individuals accepted without exposure to Leishmania.

PCR: The DNA isolation and conventional PCR were applied as described previously (12). Briefly, the DNA extraction was done using the phenol-chloroform method and for the conventional PCR, 13A (5' GTG GGG GAG GGG CGT TCT 3') and 13B (5' ATT TTA CAC CAA CCC CCA GTT $3^{\prime}$ ) primers were used.

Treatment: All patients received therapy with a pentavalent antimonial at a dose of $20 \mathrm{mg} \mathrm{Sb} / \mathrm{kg} /$ day given intramuscularly for 30 days. Relapsed patients were retreated with meglumine antimonate.

Statistical analysis: The Statistical Package for Social Sciences, SPSS version 10.0, was used to compare continuous normal distributed data by paired t-test, and the significance level was fixed at 0.05 .

\section{RESULTS}

Of the 20 paediatric patients, predominantly from the Aegean region of Turkey, $70 \%$ were male and $30 \%$ female. The patients median age was 46, 6 months (range, 5 months-14 years); 16 patients (80\%) were aged $\leq 5$ years. Fifty-three sera and 23 bone marrow (BM) samples taken from 20 children were tested.

With successful therapy, antibody titers declined steeply during follow-up. Three patients who showed increased titers of antibodies were treated successfully with a second cure of meglumine antimoniate. Parasitological and serological results were summarized in Table 1. Mean ELISA optical density values before and after treatment were: $0.78 \pm 0.36(0.26-1.76)$ and $0.38 \pm 0.24$ (0.09-0.83) respectively; $(p<0.001)$. Cut-off point was 0.300 OD. Mean IFAT values $\left(\log _{10}\right.$ transformed titers) before and after treatment were: $3.02 \pm 0.90$ (1.81-4.51) and 2.16 \pm 0.75 (1.20-3.90) respectively; ( $<<0.001)$. Cut-off point was 2.11 (Fig 1, 2).

Among 20 patients, relapses were detected in three patients (no: $2,8,19$ ) and occurred between 90 and 480 days after the primary diagnosis. The antibody titers of these patients gave an increase compared with the previous titers during follow up with ELISA and/or IFAT. They showed clinical symptoms and their peripheral blood samples were also found to be positive by PCR. 
Table 1. Demographic and serological characteristics of 20 cases in follow up period ( $\infty$ relapsed cases)

\begin{tabular}{|c|c|c|c|c|c|c|}
\hline $\begin{array}{l}\text { Patient } \\
\text { No. }\end{array}$ & $\begin{array}{c}\text { Age } \\
\text { (years) }\end{array}$ & Sex & $\begin{array}{c}\text { Follow- } \\
\text { up } \\
\text { (days) }\end{array}$ & IFAT* & ELISA** & $\begin{array}{c}\text { Microscopy } \\
\text { (Bone-- } \\
\text { Marrow) }\end{array}$ \\
\hline \multirow[t]{6}{*}{01} & \multirow[t]{6}{*}{9} & \multirow[t]{6}{*}{$M$} & 0 & 32000 & 0.718 & \multirow[t]{6}{*}{ POS } \\
\hline & & & 30 & 8000 & 0.494 & \\
\hline & & & 72 & 512 & 0.464 & \\
\hline & & & 127 & 128 & 0.278 & \\
\hline & & & 176 & 64 & 0.159 & \\
\hline & & & 245 & 64 & 0.161 & \\
\hline \multirow[t]{4}{*}{$02 \infty$} & \multirow[t]{4}{*}{4} & \multirow[t]{4}{*}{$M$} & 0 & 128 & 0.628 & \multirow[t]{2}{*}{ POS } \\
\hline & & & 60 & NEG & 0.092 & \\
\hline & & & 480 & 128 & 0.473 & \multirow[t]{2}{*}{ NEG } \\
\hline & & & 500 & 64 & 0.502 & \\
\hline \multirow[t]{3}{*}{03} & \multirow[t]{3}{*}{7} & \multirow[t]{3}{*}{$M$} & 0 & 16000 & 0.788 & \multirow[t]{3}{*}{ POS } \\
\hline & & & 60 & 1024 & 0.423 & \\
\hline & & & 90 & 512 & 0.371 & \\
\hline \multirow[t]{4}{*}{04} & \multirow[t]{4}{*}{4} & \multirow[t]{4}{*}{$M$} & 0 & 1024 & 1.350 & \multirow[t]{4}{*}{ POS } \\
\hline & & & 30 & 64 & 0.830 & \\
\hline & & & 90 & NEG & 0.230 & \\
\hline & & & 240 & NEG & 0.170 & \\
\hline \multirow[t]{3}{*}{05} & \multirow[t]{3}{*}{$5 / 12$} & \multirow[t]{3}{*}{$M$} & 0 & 256 & 0.768 & \multirow[t]{3}{*}{ POS } \\
\hline & & & 60 & 64 & 0.167 & \\
\hline & & & 270 & NEG & 0.147 & \\
\hline \multirow[t]{2}{*}{06} & \multirow[t]{2}{*}{2} & \multirow[t]{2}{*}{$M$} & 0 & 1024 & 0.656 & POS \\
\hline & & & 60 & 64 & 0.468 & \\
\hline 07 & 1 & $M$ & 0 & 1024 & 0.823 & POS \\
\hline & & & 40 & 256 & 0.356 & \\
\hline & & & 70 & NEG & 0.288 & \\
\hline $08 \infty$ & 2 & $\mathrm{~F}$ & 0 & 256 & 0.332 & POS \\
\hline & & & 30 & 64 & 0.076 & \\
\hline & & & 90 & 64 & 0.364 & NEG \\
\hline 09 & 3.5 & $\mathrm{~F}$ & 0 & 64 & 1.020 & POS \\
\hline & & & 30 & 64 & 0.790 & \\
\hline & & & 105 & 16 & 0.140 & \\
\hline 10 & 3 & $M$ & 0 & 512 & 0.538 & POS \\
\hline & & & 60 & 128 & 0.224 & \\
\hline 11 & 1 & $\mathrm{~F}$ & 0 & 4096 & 1.764 & POS \\
\hline & & & 55 & 2048 & 0.810 & \\
\hline 12 & 7 & $M$ & 0 & 256 & 0.260 & POS \\
\hline & & & 90 & 16 & 0.194 & \\
\hline 13 & 2 & $M$ & 0 & 32000 & 0.780 & POS \\
\hline & & & 30 & 512 & 0.435 & \\
\hline 14 & 5 & $M$ & 0 & 4096 & 0.648 & POS \\
\hline & & & 90 & 256 & 0.099 & \\
\hline 15 & 14 & $M$ & 0 & 4096 & 0.960 & POS \\
\hline & & & 150 & 256 & 0.153 & \\
\hline
\end{tabular}

\begin{tabular}{|l|c|c|c|c|c|c|}
\hline 16 & 1.5 & $F$ & 0 & 64 & 0.730 & POS \\
\cline { 4 - 6 } & & & 210 & 16 & 0.286 & \\
\hline 17 & 1.5 & $F$ & 0 & 128 & 0.600 & \multirow{2}{*}{ POS } \\
\cline { 4 - 6 } & & & 30 & 64 & 0.343 & \\
\hline 18 & 2 & $\mathrm{M}$ & 0 & 64 & 0.303 & \multirow{2}{*}{ POS } \\
\cline { 4 - 6 } & & & 60 & 16 & 0.243 & \\
\hline $19 \infty$ & 5 & $\mathrm{~F}$ & 0 & 512 & 0.335 & POS \\
\cline { 4 - 6 } & & & 90 & 128 & 0.650 & NEG \\
\hline 20 & 2 & $\mathrm{M}$ & 0 & 2048 & 0.475 & POS \\
\cline { 4 - 6 } & & & 30 & 64 & 0.088 & \\
\hline
\end{tabular}

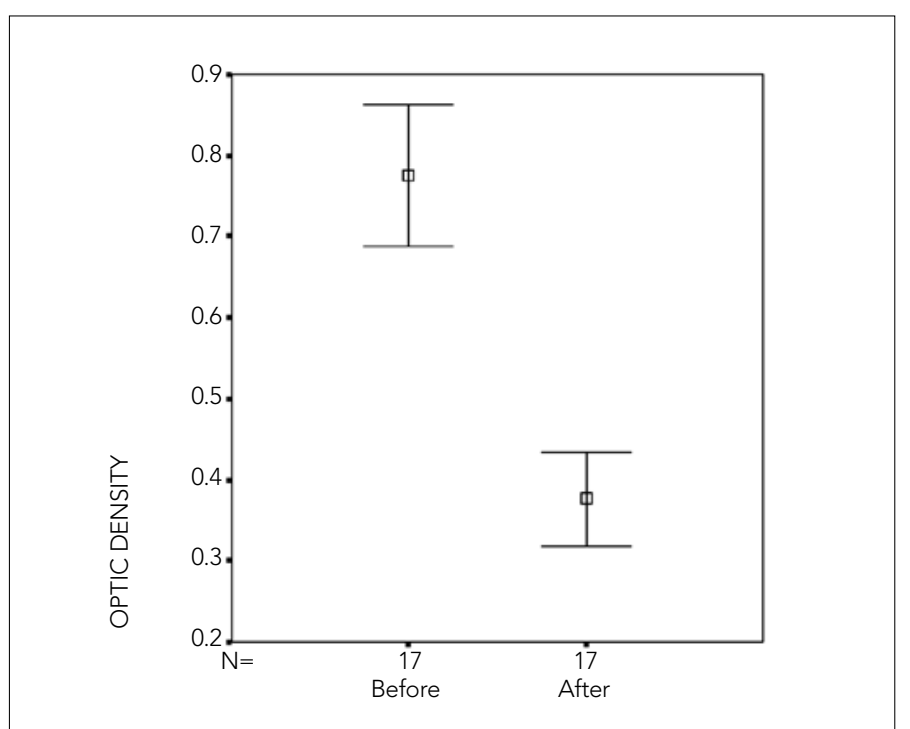

Figure 1. Mean ELISA optic density values before and after treatment were: $0.78 \pm 0.36(0.26-1.76)$ and $0.38 \pm 0.24(0.09-0.83)$ respectively, $(p<0.001)$. Cut-off point $=0.300$ OD (In cured patients)

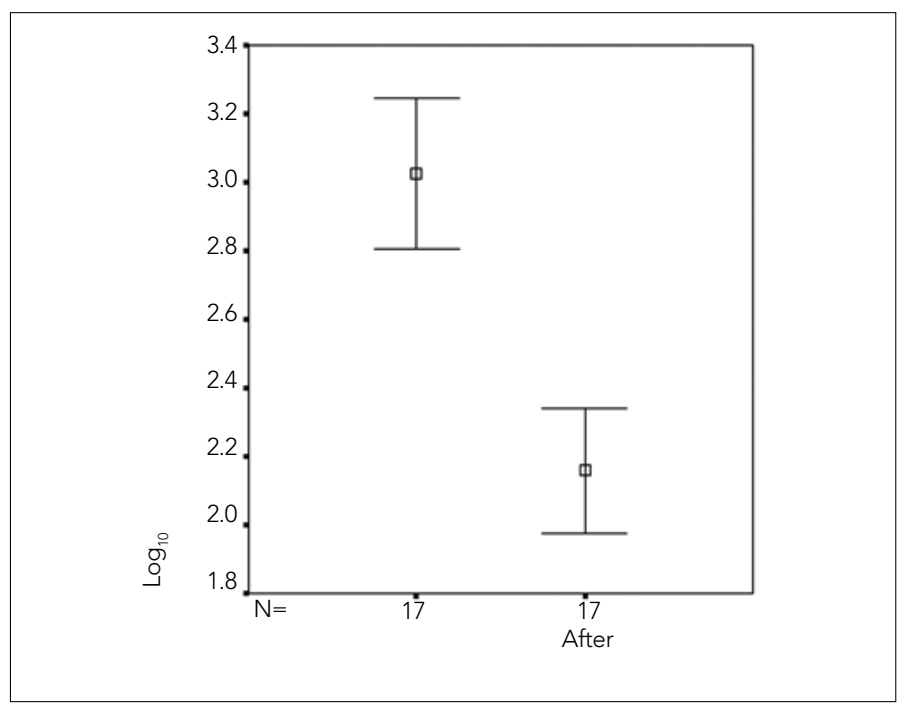

Figure 2. Mean IFA values ( $\log _{10}$ transformed titers) before and after treatment were: $3.02 \pm 0.90(1.81-4.51)$ and $2.16 \pm 0.75(1.20$ 3.90) respectively, $(p<0.001)$. Cut-off point $=2.11$ (In cured patients) 
Interestingly, the titers in ELISA in two patients (8 and 19) after the relapse were higher than the first diagnosis values, while the titer was lower in patient 2.

\section{DISCUSSION}

Leishmaniasis is a group of vector borne disease, affecting 98 countries or territories, with more than 350 million people at risk. Visceral leishmaniasis (VL) is the most serious form, which is fatal if left untreated, and the annual incidence is estimated as 500,000 cases worldwide $(1,13)$. In endemic areas, the disease tends to be relatively chronic, and children are especially affected. Until recently, the age group most affected by endemic visceral leishmaniasis caused by L. infantum in southern Europe, North Africa and West and Central Asia was 1-4 years (13). The median age of our patients was 46, 6 months, (range: 5 months -14 years) and $80 \%$ of the children were younger than $\leq 5$ years. These findings were also similar to those reported in the other Mediterranean countries and Turkey (13-20).

Visualization of the amastigote form of the parasite by microscopic examination of tissue aspirates is the classical confirmatory test for Visceral leishmaniasis. Culturing of blood or organ aspirates increases the sensitivity of diagnosis (13). Several serologic tests varying in terms of sensitivity and specificity are the most practical way of diagnosing VL infections (2-6). On the other hand, different PCR assays have been developed for diagnosing and monitoring leishmaniasis. This technique has been shown to be more useful than conventional diagnostic methods, due to its greater sensitivity (21-24).

In this study, with successful therapy, antibody titers declined steeply during follow-up. Among 20 patients, relapses were detected in three patients. The antibody titers of these patients showed an increase compared with the previous titers during follow up with ELISA and/or IFAT. They showed clinical symptoms and their peripheral blood samples were also found to be positive by PCR. This is the first report of follow-up by serological tests of pediatric visceral leishmaniasis in Turkey. ELISA and IFAT are simple, inexpensive, non-invasive and valuable in monitoring drug therapy and detecting relapse of $\mathrm{VL}$ among children. The sharp decline in titers correlated well with a definite cure and can be applied to the hospital routine, whereas in relapsing patients a rise after an initial fall was a good indicator.

We recommend the use of IFAT and ELISA tests for follow up of visceral leishmaniasis. We conclude that primary diagnosis and post therapeutic monitoring by IFAT and ELISA tests for children is recommended.

\section{Acknowledgement}

We appreciate the statistical analysis performed by Sevgi Eskiocak.

\section{Conflict of Interest}

No conflict of interest was declared by the authors.

\section{REFERENCES}

1. Desjeux P. Leishmaniasis: Current situation and new perspectives. Comp Immunol Microbiol Infect Dis 2004; 27: 305-18. [CrossRef]

2. Kafetzis DA. An overview of paediatric leishmaniasis. J Postgrad Med 2003; 49: 31-8. [CrossRef]

3. Hailu A. Pre- and post-treatment antibody levels in visceral leishmaniasis. Trans R Soc Trop Med Hyg 1990; 84: 673-5. [CrossRef]
4. Kumar R, Pai K, Pathak K, Sundar S. Enzyme-linked immunosorbent assay for recombinant K39 antigen in diagnosis and prognosis of Indian visceral leishmaniasis. Clin Diagn Lab Immunol 2001; 8: 1220-4. [CrossRef]

5. Kumar P, Pai K, Tripathi K, Pandey HP, Sundar S. Immunoblot analysis of the humoral immune response to Leishmania donovani polypeptides in cases of human visceral leishmaniasis: its usefulness in prognosis. Clin Diagn Lab Immunol 2002; 9: 1119-23. [CrossRef]

6. Millesimo M, Zucca M, Caramello P, Savoia D. Evaluation of the immune response in visceral leishmaniasis. Diagn Microbiol Infect Dis 1996; 26: 7-11. [CrossRef]

7. Sundar S, Rai M. Laboratory diagnosis of visceral leishmaniasis. Clin Diagn Lab Immunol 2002; 9: 951-8. [CrossRef]

8. de Korte PM, Harith AE, Dereure J, Huigen E, Faucherre $V$, van der Kaay HJ. Introduction of an improved direct agglutination test for the detection of Leishmania infantum infection in southern France. Parasitol Res 1990; 76: 526-30. [CrossRef]

9. Abranches P, Silva-Pereira MC, Conceição-Silva FM, Santos-Gomes GM, Janz JG. Canine leishmaniasis: pathological and ecological factors influencing transmission of infections. J Parasitol 1991; 77: 557-61. [CrossRef]

10. Özbel Y, Oksam L, Özensoy S, Turgay N, Alkan MZ, Jaffe CL, et al. A survey on canine leishmaniasis in western Turkey by parasite, DNA and antibody detection assays. Acta Trop 2000; 74: 1-6.

11. Ozensoy S, Ozbel Y, Turgay N, Alkan MZ, Gul K, Gilman-Sachs A, et al. Serodiagnosis and epidemiology of visceral leishmaniasis in Turkey. Am J Trop Med Hyg 1998; 59: 363-9. [CrossRef]

12. Özensoy Töz S, Özbel Y, Atay MG, Ertabaklar H, Şakru N, Taylan Özkan A, et al. Application of Polymerase Chain Reaction (PCR) for Diagnosis of Leishmaniasis in Clinical Samples Obtained from Human and Dogs. Turkiye Parazitol Derg 2002; 26: 239-44.

13. WHO Technical Report Series: 949, Control of the Leishmaniases. Report of a meeting of the WHO Expert Committee on the Control of Leishmaniases, Geneva, 22-26 March 2010.

14. Maltezou HC, Siafas C, Mavrikou M, Spyridis P, Stavrinadis C, Karpathios T, et al. Visceral leishmaniasis during childhood in southern Greece. Clin Infect Dis 2000; 31: 1139-43. [CrossRef]

15. Minodier P, Piarroux R, Garnier JM, Unal D, Perrimond H, Dumon H. Pediatric visceral leishmaniasis in southern France. Pediatr Infect Dis J 1998; 17: 701-4. [CrossRef]

16. Cascio A, Calattini S, Colomba C, Scalamogna C, Galazzi M, Pizzuto $M$, et al. Polymerase chain reaction in the diagnosis and prognosis of Mediterranean visceral leishmaniasis in immunocompetent children. Pediatrics 2002; 109: E27. [CrossRef]

17. Ok UZ, Balcioglu IC, Taylan Ozkan A, Ozensoy S, Ozbel Y Leishmaniasis in Turkey. Acta Trop. 2002; 84: 43-8. [CrossRef]

18. Dursun $O$, Erişir $S$, Yeşilipek $A$. Visceral childhood leishmaniasis in southern Turkey: experience of twenty years. Turk J Pediatr 2009; 51: 1-5.

19. Arik Yilmaz E, Tanir G, Tuygun N, Taylan Ozkan A. Visceral leishmaniasis in 13 pediatric patients in Turkey: treatment experience. Turkiye Parazitol Derg 2009; 33: 259-62

20. Tanir G, Taylan Ozkan A, Dağlar E. Pediatric visceral Leishmaniasis in Turkey. Pediatr Int. 2006; 48: 66-9. [CrossRef]

21. Bourgeois N, Lachaud L, Reynes J, Rouanet I, Mahamat A, Bastien P. Long-term monitoring of visceral leishmaniasis in patients with AIDS: relapse risk factors, value of polymerase chain reaction, and potential impact on secondary prophylaxis. J Acquir Immune Defic Syndr 2008; 48: 13-9. [CrossRef]

22. Pizzuto M, Piazza M, Senese D, Scalamogna C, Calattini S, Corsico L, et al. Role of PCR in diagnosis and prognosis of visceral leishmaniasis in patients coinfected with human immunodeficiency virus type $1 . \mathrm{J}$ Clin Microbiol 2001; 39: 357-61. [CrossRef]

23. Cruz I, Chicharro C, Nieto J, Bailo B, Cañavate C, Figueras MC, et al. Comparison of new diagnostic tools for management of pediatric Mediterranean visceral leishmaniasis. Clin Microbiol 2006; 44: 2343-7. [CrossRef]

24. Cascio A, Colomba C, Antinori S, Orobello M, Paterson D, Titone L. Pediatric visceral leishmaniasis in Western Sicily, Italy: a retrospective analysis of 111 cases. Eur J Clin Microbiol Infect Dis 2002; 21: 277-82. [CrossRef] 